\title{
A socioeconomic analysis of GO-NGO versus self-managed dairy farming in two districts of Bangladesh
}

\author{
MT Uddin*1, K Akhi', J Begum ${ }^{3}$, MS Islam³ ${ }^{3}$ MM Khatun ${ }^{3}$ \\ ${ }^{1}$ Department of Agricultural Economics, Bangladesh Agricultural University, Mymensingh; ${ }^{2}$ Department of \\ Agricultural Economics and Policy, Sylhet Agricultural University, Sylhet; ${ }^{3}$ Socioeconomic Research Division, \\ BLRI, Savar, Dhaka, Bangladesh
}

\begin{abstract}
With a view to address the present status of intervention received by dairy farmers from different government and non-government organizations and its impact on farmers' livelihood pattern in relation to self-managed farmers, this present study was performed in two districts of Bangladesh namely, Manikganj and Sirajganj. Altogether 165 dairy farmers were selected from two districts. A combination of descriptive, statistical and mathematical techniques was applied to achieve the objectives and to get the meaningful results. The BCR were 2.3 for NGO supported and 2.4 for GO supported farmers. The productivity in terms of physical volume was higher in case of supported dairy farmers for both the areas which were tested by t-statistics. In determining the effects of the different variable inputs, four out of six variables (i.e., labor cost, paddy straw cost, green grass cost and concentrate feed cost) were found to have significant effect on gross returns from milk production for both supported and selfmanaged farmers. To accomplish the profit maximization, all types of dairy farmers have scope to attain full efficiency in milk production by reallocating the resources. Supported farm created greater opportunity for employment of both male and female than self-managed dairy farmers. Ravallion test results showed that the income was increased by the amount of Tk. 25400.6 due to intervention. Expenditure elasticity was also estimated at $0.40 \%$ which means that expenditure increased by $0.40 \%$, on an average, due to $1 \%$ increase in income, other things remaining the same. The asset pentagon approach shows that there is a noteworthy improvement based on different capitals namely, human capital, social capital, natural capital, physical capital and financial capital of supported dairy farming. Although dairy farmers reported problems of low price of output, inadequate capital, etc., these could be minimized if both government and non-government organizations take proper measures in this regard, which will ultimately lead to improve farmers' socioeconomic conditions and livelihood status.
\end{abstract}

Key words: productivity, profitability, income, expenditure, livelihood and dairy farmers.

Bangladesh Animal Husbandry Association. All rights reserved. Bang. J. Anim. Sci. 2014.43 (3): 232-241

\section{Introduction}

Bangladesh has primarily an agrarian economy and livestock is the second most important subsector of agriculture. The contribution of livestock sub-sector to GDP is 2.50 percent and it provides employment for about 25 percent of the total labor force (BER 2013). Dairy farming is an efficient and intensive system in terms of nutrient and protein production for human consumption. Milk and meat are very rich in nutrient contents which are essential for human health. Bangladesh has a shortage of milk, meat and egg of $85.9 \%$,
$88.1 \%$ and $70.7 \%$ of the total requirement, respectively (BBS 2012). To fulfill this gap, formulation of long-term plan is essential to increase the production of livestock and livestock products.

The dairy sector in Bangladesh is mainly operated by the private entrepreneurs. Most of the milk is produced by the rural households and majority of the households have 1 or 2 dairy cows. Most of these dairy cows are used for both milk production and drought purposes. There are some milk pocket areas where dairy farming has 


\section{GO- NGO versus self- managed dairy farming}

been traditionally an important and major component of mixed farming system. These areas are particularly located in the districts of Pabna, Sirajganj, Manikganj, Munshiganj, Faridpur, Madaripur, Rangpur, Tangail and Kishoreganj. In these areas there are some farmers who keep dairy cows only for milk production (Raha and Talukder 2004).

In order to promote dairy cow rearing and to increase milk production to meet increased demand, at present, government organization such as DLS, and several non-government organizations (NGOs) such as, Milk Vita, BRAC, ASA, TMSS, RAKUB, SSS, NSKF, etc. are providing incentives and supports to the dairy farmers. In Manikganj district, the important NGOs are BRAC, ASA, Grameen Bank, Nijera kori, Sojag. Especially Nijera kori and Sojag work for dairy farming in the study area. They provide credit, training, technical support, veterinary services, medicine, etc. to the dairy farmers. They also monitor the overall activities of the farmers. In Sirajganj district, important NGOs are BRAC, PROSHIKA, SSS, TMSS, Milk Vita and ASA. They provide agricultural credit and micro credit at a reasonable interest rate. Besides these, Milk Vita provides support to farmers on dairy production. It provides technical support and veterinary services to the dairy farmers as well.

From literature review, researchers found that some studies dealt with productivity, problems and prospects of dairy farming; and a few studies were also performed on reproductive performance on dairy cows; but there is no detailed research that addresses the present status of intervention, support or incentive received by dairy farmers from different government and non-government organizations and its impact on farmers' livelihood pattern in relation to self- managed farmers. The study will analyze the impact of GO/NGOs' intervention, incentive or support on farmers' livelihood status along with other forward linkages. The specific objectives of the study were as: to estimate comparative productivity and profitability between intervention and self-managed dairy farmers; to assess the effect of interventions on farmers' employment creation, income generation and livelihood pattern; and to identify major constraints and recommend solutions for necessary improvement.

\section{Materials and Methods}

Study areas were purposively selected from 02 (two) upazilas in each Sirajganj and Manikganj district where greater concentration of dairy farming is existing. The selected upazilas were Ullapara and Shahjadpur under Sirajganj district; and Shibalaya and Singair under Manikganj district. Altogether 165 dairy farmers were selected from two districts. Eighty five farmers were selected taking 30 farmers receiving incentives from different government organizations, and 55 farmers supported by different non-government organizations. Interviews were also conducted with 50 selfmanaged dairy farmers taking 20 from Ullapara upazila of Sirajgonj district and 15 from each upazila of Manikganj district. The simple random sampling technique was followed to select the dairy farmers. Field survey method and focus group discussions were followed to collect primary data and information. A combination of descriptive, statistical and mathematical techniques was applied to achieve the objectives and to get the meaningful results.

Productivity can be defined as the ratio of farm output to input used or resource used. Profitability was derived in terms of gross return, gross margin, net return and benefit cost ratio (undiscounted). The formula used for the calculation of financial profitability is discussed below:

$$
\begin{gathered}
\prod=\sum_{i=1}^{n}\left(P_{Y_{i}} \cdot Y_{i}\right)-\sum_{i=1}^{n}\left(P_{X_{i}} \cdot X_{i}\right)-T F C \\
\text { Where, } \\
\prod=\text { Net return; } \\
P_{Y_{i}}=\text { Price per unit of the } \mathrm{i}^{\text {th }} \text { product; } \\
Y_{i}=\text { Quantity of the } \mathrm{i}^{\text {th }} \text { product; }
\end{gathered}
$$




$$
\begin{aligned}
P_{X_{i}} & =\text { Price per unit of } \mathrm{i}^{\text {th }} \text { input; } \\
X_{i} & =\text { Quantity of the } \mathrm{i}^{\text {th }} \text { input; } \\
\text { TFC } & =\text { Total fixed cost; } \\
\mathrm{i} & =1,2,3, \ldots, \mathrm{n} \text { (number of items). }
\end{aligned}
$$

Here, gross return is the summation of monetary value of net change in inventory of dairy and dairy production. The net change in inventory was estimated by using the following formula:

Net change in inventory $=$ (Closing stock + Consumed/ gifted + Sold+ Died) - (Opening stock + Bought)

$B C R$ was estimated as a ratio of gross returns and gross costs. The formula of calculating BCR (undiscounted) is shown as below:

Benefit cost ratio $=\frac{\text { Gross benefit }}{\text { Gross cost }}$

Cobb-Douglas production function model was used to determine the effects of key variables on milk production. To identify the most important variables in the production process of milk of dairy farms, the specification of the model was made as follows:

$Y_{i}=\mathrm{aX}_{1}{ }^{\mathrm{b} 1} \mathrm{X}_{2}{ }^{\mathrm{b} 2} \mathrm{X}_{3}{ }^{\mathrm{b} 3} \mathrm{X}_{4}{ }^{\mathrm{b} 4} \mathrm{X}_{5}{ }^{\mathrm{b} 5} \mathrm{X}_{6}{ }^{\mathrm{b} 6} \mathrm{e}^{\mathrm{u}}{ }_{\mathrm{i}}$

The Cobb-Douglas production function was transformed into following logarithmic form so that it could be estimated by the ordinary least squares (OLS) method:

$\ln Y=\ln a+b_{1} \ln X_{1}+b_{2} \ln X_{2}+b_{3} \ln X_{3}+b_{4}$ $\ln X_{4}+b_{5} \ln X_{5}+b_{6} \ln X_{6}+u_{i}$

Where,

$Y=$ Value of milk yield (Tk. /Yr);

$\mathrm{X}_{1}=$ Labor cost $(\mathrm{Tk} . / \mathrm{Yr})$;

$\mathrm{X}_{2}=$ Paddy straw cost $(\mathrm{Tk} . / \mathrm{Yr})$;

$X_{3}=$ Green grass cost $(T k . / Y r)$;

$\mathrm{X}_{4}=$ Concentrate feed cost $(T k . / Y r)$;

$\mathrm{X}_{5}=$ Veterinary cost $(T k . / \mathrm{Yr})$;

$X_{6}=$ Housing cost $(T k . / Y r)$;

In = Natural logarithm;

$\mathrm{a}=$ Constant $/$ intercept;

$b_{1}, b_{2 \ldots} . . b_{6}=$ Production coefficients of the respective variables; and

$\mathrm{u}_{\mathrm{i}}=$ Error term.
The optimum use of a particular input would be ascertained by the equation of equality of MVP and MFC, i.e., $\mathrm{MVP}_{\mathrm{xi}} / \mathrm{MFC}_{\mathrm{xi}}=1$.

The impacts of dairy farming program of $\mathrm{GO}$ and NGO on income generation were measured by using the before and after comparison with the help of the following formula:

$$
\text { I }=\frac{1}{n} \sum_{i=1}^{n}\left(O_{i}^{T}-O_{i}^{C}\right) \quad(\text { Ravallion 2008) }
$$

Where,

$$
\begin{aligned}
& \text { I = Average causal effect; } \\
& \mathrm{n}=\text { Sample size; } \\
& \mathrm{i}=\text { Sample units; } \\
& \mathrm{O}=\text { Value of the interpretable impact }
\end{aligned}
$$
indicator;

$\mathrm{T}=$ Treatment group; and $\mathrm{C}=$ Control group.

The paired sample $t$ test was applied to verify the significance of relevant parameters.

Expenditure elasticity was also estimated using the following formula:

$$
\mathrm{E}_{\mathrm{Y}}=\frac{\mathrm{AY}}{\mathrm{SI}} \times \frac{I}{Y}
$$

Where,

$\mathrm{E}_{\mathrm{Y}}=$ Expenditure elasticity;

$\Delta \mathrm{Y}=$ Change in expenditure;

$\Delta \mathrm{I}=$ Change in income;

$\mathrm{I}=$ Income before intervention; and

$Y=$ Expenditure before intervention.

To address the livelihood pattern of the respondents, the sustainable livelihood framework analysis including the asset pentagon was followed (DFID 2000). Finally, problems related to technical, production and marketing were addressed and possible suggestions were provided by the farmers for expanding GO/NGOs' intervention for policy options.

\section{Results and Discussions}

\section{Socioeconomic characteristics of the live- stock farmers}

In the present study, the sample farmers were classified into three age groups such as, 0-14 


\section{GO- NGO versus self- managed dairy farming}

years 15-64 years and above 64 years (HIES 2010). Table 1 shows that average family size was higher than the national average for selfmanaged and GO supported dairy sample farmers but it was almost equal to the national average of 4.53 (HIES 2010) for NGO supported farmers. The data indicated that majority of the family members were in secondary level of education. The literacy rate for the family members of dairy farmers were even higher than the national context, where the statistics of literacy is claimed to be 57.91 percent (HIES 2010).

Table 2 reveals the average land holdings of the dairy farmers where farm size was measured using the following formula (Yang 1965):

Farm Size $=$ Homestead area + Owned cultivable land + Rented/mortgaged/leased-in land + Area under pond + Current fallow land - Rented/ mortgaged/leased-out land

It was observed that $\mathrm{NGO}$ and $\mathrm{GO}$ supported dairy farmers had higher farm size ( 1.8 acre and 1.6 acre, respectively) than the self-managed dairy farmers ( 1.50 acre). Agriculture is the main source of employment and $48.7 \%, 41.9 \%$ and $40.3 \%$ farmers were directly engaged in agriculture for self-managed, NGO supported and GO supported farmers, respectively in the study area (Table 2).

\section{Productivity and profitability of dairy farming}

In table 3, costs were calculated for all the family supplied and purchased inputs used for the dairy farming. In case of family supplied inputs, opportunity cost principle was applied to estimate the actual cost.

The benefit cost ratio (BCR) for all groups indicate that dairy farming was profitable. The BCR were 2.3 for NGO supported and 2.4 for GO supported which indicates that the dairy farming was more profitable under intervention than selfmanaged dairy farmers. Uddin et al. (2012) found that benefit cost ratio were 1.26 and 1.52 for local breed and cross breed dairy farmers, respectively indicated that dairy cattle rearing were profitable. Mandal et al. (2009) also found that undiscounted benefit cost ratio of milk production was 1.41, implying that milk production as an enterprise was profitable from individual farmers' point of view.

Table 1. Family size, age, sex distribution and educational status of sample farmers

\begin{tabular}{|c|c|c|c|c|c|c|c|c|c|}
\hline \multirow{2}{*}{ Particulars } & \multicolumn{3}{|c|}{ Self-managed } & \multicolumn{3}{|c|}{ NGO supported } & \multicolumn{3}{|c|}{ GO supported } \\
\hline & Male & Female & Total & Male & Female & Total & Male & Female & Total \\
\hline \multicolumn{10}{|l|}{ Age groups } \\
\hline $0-14$ & 33 & 32 & $65(34.4)$ & 29 & 28 & $57(31.5)$ & 12 & 15 & $27(29.3)$ \\
\hline $15-64$ & 55 & 53 & 108 (57.1) & 56 & 53 & $109(60.2)$ & 30 & 32 & $62(67.4)$ \\
\hline Above 64 & 9 & 7 & $16(8.5)$ & 8 & 7 & $15(8.3)$ & 2 & 1 & $3(3.3)$ \\
\hline Total & 97 & 92 & $189(100.0)$ & 93 & 88 & $181(100.0)$ & 44 & 48 & $92(100.0)$ \\
\hline Average & 2.4 & 2.3 & 4.7 & 2.3 & 2.2 & 4.5 & 2.2 & 2.4 & 4.6 \\
\hline \multicolumn{10}{|l|}{ Literacy level } \\
\hline Illiterate & 2 & 5 & $7(5.7)$ & 1 & 5 & $6(4.9)$ & 1 & 1 & $2(3.4)$ \\
\hline Primary & 21 & 28 & $49(39.8)$ & 27 & 23 & $50(40.6)$ & 9 & 10 & $19(32.8)$ \\
\hline Secondary & 28 & 29 & $57(46.3)$ & 30 & 28 & $58(47.2)$ & 15 & 12 & $27(46.6)$ \\
\hline Higher secondary & 5 & 3 & $8(6.6)$ & 5 & 3 & $8(6.5)$ & 8 & 1 & $9(15.5)$ \\
\hline Graduation & 2 & 0 & $2(1.6)$ & 1 & 0 & $1(0.8)$ & 1 & 0 & $1(1.7)$ \\
\hline Total & 58 & 65 & $123(100.0)$ & 64 & 59 & $123(100.0)$ & 34 & 24 & $58(100.0)$ \\
\hline
\end{tabular}

Source: Field survey, 2014.; Note: Figures within the parentheses indicate percentages of total. 
Uddin et al. (2014) Bang. J. Anim. Sci. 43 (3): 232- 241

Table 2. Average land holdings and occupation of dairy farmers

\begin{tabular}{|c|c|c|c|c|c|c|c|}
\hline Types of land & $\begin{array}{c}\text { Self- } \\
\text { managed } \\
\text { (acre) }\end{array}$ & $\begin{array}{c}\text { NGO } \\
\text { supported } \\
\text { (acre) }\end{array}$ & $\begin{array}{c}\text { GO } \\
\text { supported } \\
\text { (acre) }\end{array}$ & Occupation & $\begin{array}{c}\text { Self- } \\
\text { managed }\end{array}$ & $\begin{array}{c}\text { NGO } \\
\text { supported }\end{array}$ & $\begin{array}{c}\text { GO } \\
\text { supported }\end{array}$ \\
\hline Homestead area & $0.22(14.8)$ & $0.28(15.5)$ & $0.27(16.9)$ & Agriculture & 48.7 & 41.9 & 40.3 \\
\hline Owned cultivable area & $1.1(74.4)$ & $1.3(72.1)$ & $1.1(69.8)$ & Service & 1.8 & 3.0 & 2.6 \\
\hline Rented/mortgage/leased-in area & $0.04(2.8)$ & $0.04(2.1)$ & $0.03(1.9)$ & Business & 2.6 & 3.6 & 4.0 \\
\hline Rented/mortgage/leased-out area & $0.03(2.0)$ & $0.02(1.1)$ & $0.02(1.3)$ & Agriculture+Service & 8.8 & 12.2 & 11.5 \\
\hline Pond area & $0.13(8.7)$ & $0.15(8.0)$ & $0.14(8.8)$ & Agriculture+Business & 19.5 & 20.2 & 21.6 \\
\hline Pasture area & $0.02(1.3)$ & $0.06(3.2)$ & $0.06(3.9)$ & Agriculture+others & 18.6 & 19.1 & 20.0 \\
\hline Total & $1.5(100)$ & $1.8(100.0)$ & $1.6(100)$ & Total & 100.0 & 100.0 & 100.0 \\
\hline
\end{tabular}

Source: Field survey 2014; Figures within the parentheses indicate percentages of total

Table 3. Total cost and return of dairy farming in the study areas (Tk. / dairy cow/year)

\begin{tabular}{|c|c|c|c|c|c|c|}
\hline \multirow[t]{2}{*}{ Items } & \multicolumn{2}{|c|}{ Self-managed } & \multicolumn{2}{|c|}{ NGO supported } & \multicolumn{2}{|c|}{ GO supported } \\
\hline & Amount & $\%$ of total & Amount & $\%$ of total & Amount & $\%$ of total \\
\hline \multicolumn{7}{|l|}{ Cost items } \\
\hline Labor cost & 5941.5 & 17.4 & 6607.3 & 17.2 & 6115.0 & 16.7 \\
\hline Feed cost & 18219.2 & 53.4 & 21294.5 & 55.4 & 20102.5 & 55.1 \\
\hline Veterinary cost & 1216.1 & 3.6 & 1067.4 & 2.8 & 1041.6 & 2.9 \\
\hline Miscellaneous cost & 579.4 & 1.7 & 616.2 & 1.6 & 626.4 & 1.7 \\
\hline Interest on operating cost & 1557.4 & 4.6 & 1775.1 & 4.6 & 1673.1 & 4.6 \\
\hline Total variable cost (TVC) & 27513.6 & 80.7 & 31360.5 & 81.7 & 29558.6 & 80.9 \\
\hline Housing & 1179.5 & 3.5 & 1195.4 & 3.2 & 1245.0 & 3.5 \\
\hline Interest on capital invested & 5400.0 & 15.8 & 5850.0 & 15.2 & 5740.0 & 15.6 \\
\hline Total fixed cost (TFC) & 6579.5 & 19.3 & 7045.4 & 18.3 & 6985.0 & 19.0 \\
\hline Total cost (TC) & 34093.1 & 100.0 & 38405.9 & 100.0 & 36543.6 & 100.0 \\
\hline \multicolumn{7}{|l|}{ Return items } \\
\hline Milk & 12661.7 & 20.7 & 35290.6 & 40.5 & 36178.0 & 40.6 \\
\hline Net change in inventory & 47695.5 & 77.8 & 50914.0 & 58.3 & 51860.5 & 58.2 \\
\hline Others & 930.4 & 1.5 & 1020.4 & 1.2 & 1106.9 & 1.2 \\
\hline Gross return (GR) & 61287.6 & 100.0 & 87225.0 & 100.0 & 89145.4 & 100.0 \\
\hline Net return $(\mathrm{NR})=(\mathrm{GR}-\mathrm{TC})$ & \multicolumn{2}{|c|}{27194.5} & \multicolumn{2}{|c|}{48819.1} & \multicolumn{2}{|c|}{52601.8} \\
\hline BCR (Undiscounted) ( GR/TC) & \multicolumn{2}{|c|}{1.8} & \multicolumn{2}{|c|}{2.3} & \multicolumn{2}{|c|}{2.4} \\
\hline
\end{tabular}

Source: Field survey and authors' estimation, 2014

Productivity and profitability of supported dairy farming was higher than the self-managed dairy farming. Due to intervention, productivity increased by the amount of 130.7 litre milk and it was significant at $5 \%$ level of probability and total financial profitability was enhanced by the amount of Tk. 26897.6 and it was significant at $1 \%$ level (Table 4 ).

\section{Determinants of milk yield and resource use efficiency}

Six individual variables (labor, paddy straw, green grass, concentrate feed, veterinary and housing costs) for production function analysis of both group of farmers were taken into account. Out of six variables, four variables (labor, paddy straw, green grass and concentrate feed costs) were found to have significant effect on gross returns from milk production for both selfmanaged and NGO supported farmers (Table 5). 


\section{GO- NGO versus self- managed dairy farming}

Table 4. Change of intervention on productivity and profitability of dairy farmers

\begin{tabular}{lccccc}
\hline & \multicolumn{2}{c}{ Productivity basis $\dagger$} & \multicolumn{3}{c}{ Profitability basis¥ } \\
\hline SF & $\begin{array}{c}\text { Self- } \\
\text { managed }\end{array}$ & Change & SF & $\begin{array}{c}\text { Self- } \\
\text { managed }\end{array}$ & Change \\
\hline 1540 & 1409.5 & 130.7 & 88185 & 61287.6 & 26897.6 \\
& & $\left(2.1^{* *}\right)$ & & & $\left(3.3^{* *}\right)$ \\
\hline
\end{tabular}

Source: Authors' estimation 2014; $t$, physical amount of milk production; $¥$, monetary value of milk, inventory change and others; $S F$, supported farming; Figures within the parentheses indicate $t$ value.; ${ }^{* *}, p<0.01$ l; **, $p<0.05$

The estimated values of coefficients and related statistics of Cobb-Douglas production function of dairy farmers were in line with the study of Uddin et al. (2012) where paddy straw, green grass were found statistically significant at $1 \%$ level and concentrate feed, human labor and veterinary cost were found statistically significant at $5 \%$ level.

The coefficient of multiple determination, $R^{2}$ of the model was 0.564 for self-managed and 0.742 for NGO supported farmers which indicated that about 56 percent and 74 percent of the total variation in gross return under both self-managed and NGO supported dairy farmers have been explained by the variables included in the model. The F-values of the model derived for dairy farmers were highly significant at 1 percent probability level implying that all the explanatory variables included in the model were important for explaining the variation in gross return for dairy cattle rearing. Both $\mathrm{R}^{2}$ and $\mathrm{F}$-values are consistent with the study of Yasmin and Uddin (2012).

Table 6 shows that the ratios of marginal value product (MVP) and marginal factor cost (MFC) for all the variables were greater than unity indicating that more return may be obtained by increasing the use of these resources. As these ratios of MVP and MFC were not equal to one, the inequalities indicate that the farmers in the study area have failed to show their efficiency in using all the resources. Therefore, both self-managed and NGO supported dairy farmers in the study area have scope to attain full efficiency in milk production by reallocating their existing resources. The result of resource use efficiency of the present study is also supported in some extent by the findings of the study Yasmin and Uddin (2012).

Table 5. Estimated values of coefficients and related statistics of Cobb- Douglas production function of dairy farmers

\begin{tabular}{lcccc}
\hline \multirow{2}{*}{ Explanatory variables } & \multicolumn{2}{c}{ Self-managed farming } & \multicolumn{2}{c}{ GO and NGO supported farming } \\
\cline { 2 - 5 } & Value of coefficient & t value & Value of coefficient & t value \\
\hline Intercept & $3.056(0.0614)$ & 4.977 & $3.120(0.609)$ & 5.123 \\
Labor cost $\left(\mathrm{X}_{1}\right)$ & $1.120^{* *}(0.379)$ & 2.955 & $1.142^{* *}(0.278)$ & 4.107 \\
Paddy straw cost $\left(\mathrm{X}_{2}\right)$ & $1.015^{* * *}(0.542)$ & 1.872 & $1.143^{* * *}(0.564)$ & 2.026 \\
Green grass cost $\left(\mathrm{X}_{3}\right)$ & $1.021^{* *}(0.653)$ & 1.563 & $1.093^{* *}(0.421)$ & 2.596 \\
Concentrate feed cost $\left(\mathrm{X}_{4}\right)$ & $0.420^{* *}(0.613)$ & 0.685 & $0.564^{* *}(0.125)$ & 4.512 \\
Veterinary cost $\left(\mathrm{X}_{5}\right)$ & $0.281(0.214)$ & 1.313 & $0.561(0.196)$ & 2.862 \\
Housing cost $\left(\mathrm{X}_{6}\right)$ & $0.545(0.243)$ & 2.242 & $0.831(0.353)$ & 2.354 \\
\hline $\mathrm{R}^{2}$ & 0.564 & & 0.742 & 39.214 \\
F-Value & 31.541 & & & \\
\hline
\end{tabular}

Source: Authors' calculation 2014.; Figures in the parentheses indicate standard error; ${ }^{* \star}, p<0.01 ; * \star, p<0.05$ 
Uddin et al. (2014) Bang. J. Anim. Sci. 43 (3): 232- 241

Table 6. Marginal value product and resource use efficiency

\begin{tabular}{|c|c|c|c|c|c|}
\hline Variables & Geometric mean (Antilog) & Coefficients & MVPs & MFC & MVP/MFC \\
\hline \multicolumn{6}{|c|}{ Self-managed dairy farming } \\
\hline Value of milk yield (Y) & 56.3 & - & - & 1.00 & - \\
\hline Labor cost $\left(\mathrm{X}_{1}\right)$ & 11.3 & 1.120 & 5.6 & 1.00 & 5.6 \\
\hline Paddy straw cost $\left(\mathrm{X}_{2}\right)$ & 5.31 & 1.015 & 10.8 & 1.00 & 10.8 \\
\hline Green grass cost $\left(X_{3}\right)$ & 2.34 & 1.021 & 24.6 & 1.00 & 24.6 \\
\hline Concentrate feed cost $\left(X_{4}\right)$ & 7.9 & 0.420 & 2.9 & 1.00 & 2.9 \\
\hline Veterinary cost $\left(X_{5}\right)$ & 10.6 & 0.281 & 1.5 & 1.00 & 1.5 \\
\hline Housing cost $\left(X_{6}\right)$ & 7.2 & 0.545 & 4.3 & 1.00 & 4.3 \\
\hline \multicolumn{6}{|c|}{ GO and NGO supported dairy farming } \\
\hline Value of milk yield $(\mathrm{Y})$ & 65.9 & - & - & 1.00 & - \\
\hline Labor cost $\left(X_{1}\right)$ & 15.4 & 1.142 & 4.9 & 1.00 & 4.9 \\
\hline Paddy straw cost $\left(X_{2}\right)$ & 6.5 & 1.143 & 11.6 & 1.00 & 11.6 \\
\hline Green grass cost $\left(X_{3}\right)$ & 3.1 & 1.093 & 23.2 & 1.00 & 23.2 \\
\hline Concentrate feed cost $\left(X_{4}\right)$ & 9.5 & 0.564 & 3.9 & 1.00 & 3.9 \\
\hline Veterinary cost $\left(X_{5}\right)$ & 9.1 & 0.561 & 4.1 & 1.00 & 4.1 \\
\hline Housing cost $\left(X_{6}\right)$ & 8.6 & 0.831 & 6.4 & 1.00 & 6.4 \\
\hline
\end{tabular}

Source: Authors' estimation 2014

\section{Effect of dairy farming on farmers' livelihood}

The effect on employment of GO-NGO intervention was measured by using the simple mean difference of both areas. Supported farm created greater opportunity for employment of both male and female than self-managed dairy farmers (Table 7).

Table 7. Effect of GO-NGO intervention on employment creation

\begin{tabular}{lcccc}
\hline $\begin{array}{l}\text { Average } \\
\text { employment }\end{array}$ & $\begin{array}{c}\text { Supported } \\
\text { farmers } \\
\text { (man-days) }\end{array}$ & $\begin{array}{c}\text { Self- } \\
\text { managed } \\
\text { (man-days) }\end{array}$ & Difference & P-value \\
\hline Male & 101.1 & 76.4 & 24.7 & $0.14^{\star *}$ \\
Female & 88.3 & 82.1 & 6.2 & $0.09^{\star *}$ \\
\hline
\end{tabular}

Source: Authors' estimation based on field survey 2014; **, $p<0.05$

Table 8 indicates a sharp increase in household income of farm families under NGO support. Income from dairy rearing increases at a higher rate than from other sources in the study areas.

Table 9 shows that respondents were spending large portion of their income for food items. Educational and health related expenditure were increased due to intervention.
Table 8. Annual income of farmers (in Taka)

\begin{tabular}{lccc}
\hline \multirow{2}{*}{$\begin{array}{l}\text { Sources of } \\
\text { income }\end{array}$} & \multicolumn{3}{c}{ Average annual income } \\
\cline { 2 - 4 } & Self-managed & NGO supported & GO supported \\
\hline CP & $22549.4(20.0)$ & $31520.4(22.1)$ & $27640.8(20.7)$ \\
Dairy rearing & $40840.2(36.3)$ & $50566.8(35.5)$ & $45250.1(33.8)$ \\
HE & $15035.1(13.3)$ & $20220.3(14.2)$ & $16035.1(11.9)$ \\
Business & $20290.0(17.9)$ & $28322.2(19.8)$ & $26832.5(20.1)$ \\
Service & $13000.0(11.5)$ & $11075.1(7.8)$ & $17080.9(12.8)$ \\
Labor selling & $1098.2(0.97)$ & $902.3(0.6)$ & $980.4(0.7)$ \\
Total & $112813(100)$ & $142607(100)$ & $133820(100)$ \\
\hline
\end{tabular}

Source: Authors' estimation based on field survey, 2014. ; CP, crop production; $H E$, Homestead enterprise; Figures in the parentheses indicate percentages of total

Table 9. Annual expenditure of farmers (in Taka)

\begin{tabular}{lccc}
\hline Particulars & Self-managed & NGO supported & GO supported \\
\hline Food & $278401(25.9)$ & $19874.2(16.7)$ & $18520.6(16.2)$ \\
Clothing & $10250.5(9.6)$ & $6240.5(5.3)$ & $5860.3(5.1)$ \\
Education & $7580.0(7.1)$ & $16562.3(13.9)$ & $14582.5(12.8)$ \\
Health & $6270.4(5.9)$ & $12052.0(10.1)$ & $11514.0(10.1)$ \\
Farming & $30532(28.5)$ & $31851.0(26.8)$ & $32824.8(28.8)$ \\
Housing & $184667(17.2)$ & $20743.1(17.5)$ & $19387.3(16.9)$ \\
Others & $6268.1(5.8)$ & $11523.7(9.7)$ & $11470.0(10.1)$ \\
\hline Total & $107209(100)$ & $118846.8(100)$ & $114156(100)$ \\
\hline
\end{tabular}

Source: Authors' estimation based on field survey 2014; Figures in the parentheses indicate percentages of total 


\section{GO- NGO versus self- managed dairy farming}

Because of the NGO intervention, the annual dairy farming income increased from Tk. 112813 to Tk. 138214. The Ravallion test results (Table 10) showed that the income was increased by the amount of Tk. 25400.6 due to intervention. The effect of intervention on income in both areas was significant which was verified by the value of t-statistic. Expenditure elasticity was also estimated at $0.40 \%$, which means that expenditure increased by $0.40 \%$, on an average, due to $1 \%$ increase in income, other things remaining the same.

Table 10. Effect on income and expenditure of dairy farmers

\begin{tabular}{|c|c|c|}
\hline Items & $\begin{array}{c}\text { Self- } \\
\text { managed }\end{array}$ & $\begin{array}{c}\text { NGO } \\
\text { supported }\end{array}$ \\
\hline Total annual income & 112812.9 & 138213.5 \\
\hline $\begin{array}{l}\text { Effect of intervention on income (Tk.) } \\
\text { (Ravallion test result) }\end{array}$ & \multicolumn{2}{|c|}{$25400.6^{\star \star \star}$} \\
\hline t-value & \multicolumn{2}{|c|}{3.08} \\
\hline $\begin{array}{l}\text { Effect of intervention on income } \\
\text { (percentage change) }\end{array}$ & \multicolumn{2}{|c|}{22.5} \\
\hline Total annual expenditure & 107208.6 & 116503.2 \\
\hline $\begin{array}{l}\text { Effect of intervention on expenditure (TK.) } \\
\text { (Ravallion test result) }\end{array}$ & \multicolumn{2}{|c|}{$9294.6^{\star \star \star}$} \\
\hline $\mathrm{t}$-value & \multicolumn{2}{|c|}{4.44} \\
\hline $\begin{array}{l}\text { Effect of intervention on expenditure } \\
\text { (percentage change) }\end{array}$ & \multicolumn{2}{|c|}{8.7} \\
\hline Expenditure elasticity (\%) & \multicolumn{2}{|c|}{0.40} \\
\hline
\end{tabular}

\section{Sustainable livelihood framework}

The sustainable livelihood framework includes the asset pentagon which is composed of five types of capital namely human capital, social capital, natural capital, physical capital and financial capital (DFID 2000). In Table 11, the asset pentagon approach shows that there is a noteworthy improvement based on different capitals of farm households practicing selfmanaged dairy farming in comparison to GO-NGO supported farming which is consistent with the findings of the study of Uddin et al. (2011) represented that supported farmers had a great impact on farm households' poverty reduction and livelihood patterns in comparison to selfmanaged dairy farmers.

Table 11. Livelihood status of sample farmers (\% of farm household reported)

\begin{tabular}{lcc}
\hline Asset category & $\begin{array}{c}\text { Supported farming } \\
\text { (Increased) }\end{array}$ & $\begin{array}{c}\text { Self-managed farming } \\
\text { (Increased) }\end{array}$ \\
\hline Human capital & 84.8 & 49.1 \\
Social capital & 80.1 & 47.8 \\
Natural capital & 8.2 & 6.5 \\
Financial & & \\
capital & 33.7 & 1.9 \\
Physical capital & 76.7 & 66.3 \\
\hline
\end{tabular}

Source: Authors' estimation 2014

\section{Problems faced by the farmers}

Dairy farmers receive very little out of the government's huge subsidy and little allocation of agricultural credit from various credit institutions. Major problems faced by the dairy farmers were reported as low price of output, inadequate capital and higher input cost for both type of management (Table 12). Mandal et al. (2009) identified lack of adequate capital was the major problem of dairy farmers.

Table 12. Problems and their probable solutions for the dairy farmers

\begin{tabular}{lcc}
\hline Issues & Self-managed & SF \\
\cline { 2 - 3 } & Percentage & Percentage \\
\hline Problems & & \\
\hline Higher input cost & 70.0 & 65.0 \\
Inadequate capital & 83.4 & 70.0 \\
Non availability of feeds & 72.5 & 61.3 \\
Low price of output & 88.8 & 76.3 \\
Lack of scientific knowledge & 67.5 & 17.5 \\
Livestock breeding problem & 56.3 & 23.8 \\
Lack of storage facilities & 47.5 & 17.5 \\
\hline Suggestions & & \\
\hline Make available inputs & 86.3 & 88.8 \\
Give scientific education and training & 88.1 & 86.0 \\
Fix prices of major inputs & 71.1 & 84.8 \\
Improve the training system & 71.1 & 77.3 \\
Improve artificial insemination facilities & 86.0 & 81.3 \\
Increase grazing land & 70.8 & 68.9 \\
Increase credit facilities & 68.1 & 62.6 \\
\hline
\end{tabular}

Source: Field survey 2014; SF, supported farming 
However, if both the government and nongovernment organizations take proper measures to solve these problems, such problems will be minimized and the overall dairy farming situation will be improved which will lead in increase in farmers' income (Table 12). Quddus (2012) sorted out some suggestions from farmers like as, availability of reliable and continuous technical assistance, provision of pure breed and strengthening of extension services.

\section{Conclusion and I mplications}

The present study was performed to compare the overall livelihood status of GO and NGO supported dairy farmers' with self-managed farmers. The findings of the study represent that there is a great impact of GO and NGO intervention on farmer's income as well as livelihood status. Productivity and profitability of supported dairy farming was higher than the selfmanaged due to intervention. Both self-managed and NGO supported dairy farmers were profitable and they have scope to attain full efficiency in milk production by reallocating the resources. The researchers found that NGO supported farm created greater opportunity for employment of both male and female than self-managed farmers. Dairy cattle rearing can increase the income of a dairy entrepreneur which improve the livelihood and provide round the year employment of its family labor (Islam et al. 2010). Incomes from almost all sources were increased due to such GO-NGO intervention; and income from dairy cattle rearing increases at a higher rate than from other sources in the study areas. As income as well as expenditure on own consumption increases due to intervention, overall livelihood status of dairy farmers was improved accordingly. Therefore, it can be concluded that there is greater scope to improve the overall economic condition of dairy farmers in terms of higher income and more employment generation through the intervention of $\mathrm{GO}$ and NGO. Finally, it could be recommended to make available inputs at right time and to provide scientific education and training by the concerned authority to improve the farmers' socioeconomic conditions and livelihood.

\section{References}

BBS (2012). Statistical Yearbook of Bangladesh. Bangladesh Bureau of Statistics, Statistics Division, Ministry of Planning, Government of the People's Republic of Bangladesh, Dhaka.

BER (2013). Bangladesh Economic Review, Finance Division, Ministry of Finance, Government of People's Republic of Bangladesh, Dhaka.

DFID (2000). Northwest Fisheries Extension Project-2, Livelihood Review, Livelihood assessment of communities and households and technical assistance of aquaculture technologies and methods, Department for International Development, Dhaka.

HIES (2010). Preliminary Report on Household Income and Expenditure Survey, Bureau of Statistics Division, Ministry of Planning, Government of Peoples Republic of Bangladesh, Dhaka.

Islam KM, Uddin MM, Sultana MN, Assaduzzaman M, Islam MN (2010). Distribution pattern and management practices of cross breed dairy cows in cooperative dairy production system in Bangladesh. Livestock Research for Rural Development, 22: 12-24.

Mandal GK, Mandal MAS, Rahman MS (2009). Production and marketing of milk in some selected areas of Sirajganj District. Bangladesh Journal of Agricultural Economics, 32: 105-115.

Quddus MA (2012). Adoption of dairy farming technologies by small farm holders: Practices and constraints. Bangladesh Journal of Animal Science, 41: 124-135.

Raha SK, Talukder RK (2004). Vertical integration in the dairy sector in Bangladesh-The case of Bangladesh Milk Producers' Co-operative Union Limited. Bangladesh Journal of Political economy, 20: 41-51.

Ravallion M (2008). Evaluating anti-poverty programs. In: Paul Schultz T, John A. 


\section{GO- NGO versus self- managed dairy farming}

Struass (ed.), Handbook of development economics, 4: 437-446.

Uddin MT, Islam MM, Salam S (2012). Determination of profitability and coefficients of dairy cattle production in Bangladesh. Bangladesh Journal of Livestock Research, 19: 117-119.

Uddin MT, Islam MM, Nasrin M (2011). I mpact of recent changes in livestock production pattern on farm families' livelihood and health in selected areas of Bangladesh. Bangladesh Journal of Livestock Research, 18: $52-69$.
Yang WY (1965). Methods of Farm Management Investigation for Improving Farm Productivity, Food and Agriculture Organization of the United Nations, Rome, Italy.

Yasmin S, Uddin MT (2012). Profitability of dairy cattle rearing and resource use efficiency in milk production: A comparative analysis in selected areas of Mymensingh District. The J ournal of Rural Develpment, 37: 21-41. 